\title{
Progress of Self Help Group-Bank Linkage Programme in India
}

\section{OPEN ACCESS}

Manuscript ID:

ECO-2021-09023735

Volume: 9

Issue: 2

Month: March

Year: 2021

P-ISSN: 2319-961X

E-ISSN: 2582-0192

Received: 16.01.2021

Accepted: 24.02.2021

Published: 01.03.2021

Citation:

Muthu, N. "Progress of Self Help Group-Bank Linkage Programme in India." Shanlax International Journal of Economcis, vol. 9, no. 2, 2021, pp. 41-51.

DOI:

https://doi.org/10.34293/ economics.v9i2.3735

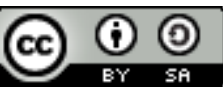

This work is licensed under a Creative Commons Attribution-ShareAlike 4.0 International License

\author{
N. Muthu \\ Assistant Professor, Department of Economics \\ Devanga Arts College, Aruppukottai, Tamil Nadu, India \\ (D) https://orcid.org/0000-0002-2724-3366
}

\begin{abstract}
In this paper an attempt has been made to analyse the progress of SHG-Bank linkage programme in India during the period between 2007-2008 and 2019-2020. The progress of SHG-Bank linkage programme has been analyzed in terms growth of savings of SHGs with banks and growth of bank loans disbursed to SHGs. For this purpose the data required for the study were collected from the official publication of National Bank for Agricultural and Rural Development (NABARD), different published reports, journals and existing available literature. This study employed simple statistical tools such as percentage analysis and averages to analyze the data. The result of the study shows that there is significant raise in the amount of savings of SHGs with banking sector and amount of loans disbursed to SHGs, During this study period. However the agency-wise analyses of savings of SHGs and loans disbursed to SHGs show that the Commercial banks lead in getting savings of SHGs and loans disbursed to them followed by Regional Rural Banks and Co-operative banks. Not with standing the remarkable progress, geographically there has been skewed development of SHG-Bank linkage programme in India. There is wide regional disparity in the spread of SHGs, savings of SHGs with banks and loans disbursed to SHGs under this programme. The outreach of this programme is spectacular in Southern region while North, West and Eastern regions are lagging behind. In view of the large outreach, predominant position and the possible benefits to the poor, it is very important to see the benefits of this programme to reach across all sections of the society and regions. So far the SHG movement is India is mostly South-Centric and it is yet to take off the real sense in other regions of India.
\end{abstract}

Keywords: SHGs, Bank linkage, Savings, Loans

\section{Introduction}

Most developing countries from 1950s to the 1980s pursued rural finance policy based on providing subsidized credit through state-controlled or directed institutions to rural people. This 'Supply led' approach in rural finance caused various qualitative issues such as concerns about financial viability of institutions on account of high rate of loan delinquency, cornering of subsidy by well off people, continued pressure of money lenders, inability to reach the core poor etc. led to a re-orientation in the thinking around 1980s. Emergence of micro credit in late 1970s and early 1980s and initial micro credit institutions in the disparate settings of Bangladesh, Bolivia and Indonesia demonstrated the success of micro-lending to poor without collateral requirements. (Mishra, Alok, 2006). Micro credit has been first started in Bangladesh by Dr.Mohammad Yunus through Grameen Bank, which was first established in 1976. Grameen Bank has adopted a simple but effective system. To obtain loans, potential borrowers must form a group of five, gather once a week for loan payment meetings. The formation of groups is the first necessary step to receive credit. Loans are initially made to two individuals in the group, who are then under pressure from the rest of the members to repay. If the borrowers default, then other members of the group may forfeit their chance of a loan. The groups perform as an institution to ensure mutual accountability. 
The Grameen Bank has provided an in-built incentive for prompt and timely repayment by the borrower i.e. gradual increase in the borrowing eligibility of subsequent loans. It is compulsory for every member to save one taka per week which is accumulated in the group fund. A member can borrow from this fund for consumption, sickness, social ceremony or even for investment. Terms and conditions are decided by the group.

In Bangladesh, what began with a small grants and loans from international donors has now provided over 100 million dollars in loans. The most distinctive feature of the credit delivery system is the absence of middlemen between the credit supplier and end-user. Today, there are more than 2300 branches of Grameen Bank with a cumulative recovery rate of $98 \%$. Now according to internal survey $58 \%$ of borrowers of Grameen Bank have moved out of poverty. Goal is to make sure that all the families connected with Grameen Bank get out of poverty by 2015 (Yunus Mohammad, 2007). The factors behind success of Grameen Bank are: Participatory process in every aspect of lending mechanism, peer pressure of group members on each other, lending for activities which generate regular income, weekly collection of loans in small amount, intense interaction with borrowers through weekly meetings, strong central management, dedicated field staff, extensive staff training, willingness to innovate, committed pragmatic leadership, and decentralized as well as participatory style of working (Tiwari,P., and Fahad, S.M., 1996). The Grameen Bank clearly shows that lack of collateral security should not stand in the way of providing credit to the poor. The poor can utilize loans and pay them if effective procedures for bank transaction with them can be established. In case of Grameen Bank, group solidarity and peer pressure have substituted for collateral security. In Bolivia, the microfinance revolution emerged in 1990s. There large scale commercial credit is provided by Banco So1, a privately owned bank for micro entrepreneurs and a number of other competitors. In Indonesia micro finance has started in 1988 with Central Bank supporting a pilot project in which 13 participating banks with the assistance of 12 NGOs have lent to about 420 SHGs in the first phase to be on-lent to their members.

\section{SHGs Bank Linkage Program in India}

In India after nationalization of commercial banks in 1969, a multi-agency Rural credit delivery structure comprising of commercial banks, Regional Rural Banks (RRBs) and co-operative banks, with a large network of more than 1,53,000 retail credit outlets has been established. Apart from massive expansion of branch network in rural areas, mandatory directed credit to priority sectors at subsidized rates of interest has been also undertaken. These measures resulted in impressive gains in rural outreach and volume of credit. As a result between 1969 and 1991, the average population per bank branch has decreased from 64,000 to 14,000 and share of institutional agencies in rural credit has increased from $7.3 \%$ in 1951 to $66 \%$ in 1991 . However, these impressive progresses made by the Indian banking sector in achieving its social goals were not without a cost. The problem at the start of 1990s were two-fold i.e. institutional structure was neither profitable in rural lending nor serving the needs of the poorest. In short, it had created a structure 'quantitatively impressive but qualitatively weak' (Mishra, Alok, 2006). Reaching the poorest, whose credit requirements were very small, frequent and unpredictable, was found to be difficult.

Further, the emphasis was on providing credit rather than financial products and services including savings, insurance, etc. to poor to meet their simple requirements (Krishnamurthy and Makarand Ratnaparkhi, 2002). Therefore, need was felt for alternative policies, systems and procedures, savings and loans products, other complementary services and new delivery mechanisms, which would fulfill the requirements of the poorest specially women. As a result, National Bank for Agricultural and Rural Development (NABARD) launched a pilot phase of SHG-Bank linkage programme in 1992. The programme is designed to integrate informal savings and credit groups with the mainstream banking system. Under the programme, NABARD refinances bank loans to SHGs, that is, it provides financing to banks at a below-market interest rate, though banks continue to carry the risk for their loans.

SHGs are mostly informal groups which are formed with the assistance of self-help promotion institutions (SHPIs) which include NGOs, 
government agencies, banks, co-operatives and microfinance institutions. In addition to helping with group formation SHPIs provide training, monitoring and other support services. SHGs collect periodic savings and make loans to their members. Savings are usually compulsory with the amount and frequency of savings collections decided by the groups. Initial loans are small ranging from Rs.100-200 and used for consumption or to repay existing debt. Overtime SHGs mobilize more savings, retain earnings and often borrow external funds enabling larger loans for consumption and business purposes. In additional to financial services some SHGs also provide health care facilities and social empowerment activities etc. Most SHGs have 10-20 members with similar socioeconomic background and from the same locality. These SHGs came to be recognized as bank clients under the pilot phase. Subsequently, bank credit is also made available to the group to augment its resources for lending to its members. It should be noted that NABARD sees the promotion and bank linkage of SHGs not as a credit programme but as part of an overall arrangement for providing financial services to the poor in a sustainable manner and also an empowerment process for the members of these SHGs.

Under the SHGs-Bank linkage programme, NGOs and banks interact with the poor, especially women, to form small homogeneous groups. These small groups are encouraged to meet frequently and collect small thrift amounts from their members and are taught simple accounting methods to enable them to maintain their accounts. Although individually these poor could never have enough savings to open a bank account, the pooled savings enable them to open a formal bank account in the name of the group. This is the first step in establishing links with the formal banking system. Groups then, meet often and use the pooled thrift to impart small loans to members for meeting their small emergent needs. This saves them from usurious debt traps and thus begins their empowerment through group dynamics, decision-making, and funds management. Gradually the pooled thrift grows and soon they are ready to receive external funds in multiples of their group savings. Bank loans enable the group members to undertake income-generating activities (Hema
Bansal, 2002). There are several advantages of the group lending setup. For one, rather than a bank, borrowers themselves undertake the task of credit evaluation; this creates a peer screening effect and reduces the transaction costs as community members have much better information than banks (Andersen and Nina, 1998). Two, there is the peer monitoring effect that induces group members to use their loans in productive ways; Three, the desire to preserve valuable social ties induces borrowers to spend extra effort if necessary to secure timely payments.

Moreover, a very important feature of group lending is the collateral effect. Bank's losses incurred due to unsuccessful projects are generally reduced a successful entrepreneurs within each group cover part of their losses (Andersen and Nina, 1998). The linkage of SHGs with banks has cut down the transaction costs for both banks and their rural clients.

SHG-Bank linkage programme has come a long way since 1992 passing through stages of pilot (1992-95), mainstreaming (1995-98) and expansion phase (1998 onwards) and emerged as the biggest microfinance programme in terms of outreach linking of 79.60 lakh SHGs linked with banks as on March 2012. This has enabled estimated 9.7 crores poor households in the country to gain access to microfinance facilities from the formal banking system. An important feature of this programme is its popularity among women - over $90 \%$ of SHGs comprised of only women members (NABARD, 2012). Through active participation of women in this programme, the process of economic empowerment of women in India can be successfully achieved. The self help group model with bank lending to groups of poor women without collateral has become an accepted part of rural finance. In India forming and nurturing small, homogeneous and participatory SHGs of the poor has today emerged as a potent tool for human development. This process enables the poor, especially the women from the poor households, to collectively identify and analyze the problems they face in the perspective of their social and economic environment. It helps them to pool their meager resources, human and financial, and priorities the use of resources for solving their own problems. SHGs-Bank linkage programme has 
proved to be the major supplementary credit delivery system with wide acceptance by banks, NGOs and various government departments.

In India, the first survey on SHGs has been undertaken by NABARD, along with other Indian members of the Asian and Pacific Regional Agricultural Credit Association (APRACA). They have conducted an action research on linking SHGs with the concept of savings and credit in 1987 and have published the outcome of the research in the form of a survey report in 1989. The survey has been carried out in the form of case studies of 46 SHGs spread over 11 states and associated with 20 Self Help Group Promoting Institutions. The first impact study of NABARD on SHG-Bank linkage programme has been carried out by Puhazhendhi and Satyasai for NABARD in 2000. The study has assessed the impact of microfinance on socio-economic conditions of 560 household members from 223 SHGs located in 11 states; Rajasthan (Northern region), Orissa and West Bengal (Eastern region), Madhya Pradesh and Utter Pradesh (Central region), Gujarat and Maharashtra (Western region), and Andhra Pradesh, Karnataka and Tamil Nadu (Southern region). This study has stated that the composite index of different socioeconomic parameters increased from 40 to 65 from the pre-SHG to post-SHG period.

Another impact study on SHG Linkage Programme in India has been carried out by Puhazhendi and Badatya in 2002. The study has assessed the impact on SHG members in three eastern states, i.e., Orissa, Jharkhand and Chattisgarh. The overall findings of the study suggest that the SHGBank linkage programme has made a significant contribution to social and economic improvement of SHG members. The study on SHGs conducted by EDA Rural System and Andhra Pradesh Mahila Abhivrudhi (APMAS) (2006) on the SHG-Bank linkage programme in India, has addressed a wide range of issues including cases of dropouts from SHGs and internal politics, and issues of social harmony and social justice, community actions, book-keepings, equity, defaults and recoveries and sustainability of SHGs. A study carried out by Ramakrishna (2006) of the NABARD GTZ Rural Finance Programme has assessed the SHG-bank linkage programme from the survey data that was collected from 27 public sector banks, 192 regional rural banks and 114 cooperative credit institutions in Tamil Nadu, West Bengal, Karnataka, Chhatisgarh and Maharashtra. The study has reported that commercial banks had a major share of the market at 61 per cent of total number of active SHG members and 68 per cent of the share in the number of loans outstanding to these SHGs. As compared to 61 per cent market share of commercial banks, the RRBs' market share has 30 per cent and cooperative banks had very small market share of 9 per cent in the SHG-Bank linkage programme.

\section{Significance of the Study}

SHGs-Bank Linkage programme was launched by NABARD as a pilot project in February 1972 to solve the failures of Indian government to reach the financial expanding to poor. The strategy behind SHG-Bank linkage programme is to form small, cohesive and participative groups of the poor and encourage them to pool their savings regularly and use the pool savings in order to make small interestbearing loans available to the members. Under this programme NGOs and Banks interact with poor, especially women, to form small homogeneous groups. These small groups are encouraged to meet frequently and collect small thrift amounts from their members are taught simple accounting methods to enable them often and use the pooled thrift to impart small loans to members for meeting their small emergent needs.

Not with standing the remarkable progress, geographically there has been skewed development of SHGs-Bank linkage programme in India. There is wide regional disparity in the spread of SHGs, savings of SHGs with banks and loans disbursed to SHGs under this programme. In March 2020 while the southern region accounts 36.01 per cent of the total number of the SHGs in India, the share of northern region is just 5.44 per cent. In terms of savings of SHGs southern region accounts 56.21 per cent where as north-eastern region accounts only 1.83 per cent in the total savings. In terms of loans disbursed to SHGs, the regional-wise differential gets further magnified. The outreach of this programme is spectacular in southern region while North, West and Eastern regions are lagging behind. In view of 
the large outreach, predominant position and the possible benefits to the poor, it is very important to see the benefits of this programme to reach across all sections of the society and regions. So far the SHG movement is India is mostly South-Centric and it is yet to take off the real sense in other regions of India.

The NABARD introduced SHG-Bank linkage program as a pilot project to achieve the mission of reaching those families who did not access to credit by any formal financial institutions and therefore, we're dependent on informal sources and money lenders. The Bank of India advised commercial banks to participate actively in this program, this program was further extended to regional rural banks and co-operative banks. Commercial banks lead in getting savings of SHGs and loans disbursed to them. More than half 62.36 percent, are financed by commercial banks, followed by regional rural banks 31.20 percent and co-operative banks 6.44 percent. There is a difference in the agency-wise distribution of bank loans disbursed to SHGs.

SHG-Bank linkage program has now reached a staggering one crore SHGs covering more than 12 crores of poor households. However, despite the success of the SHG-Bank linkage program which enabled millions of SHG members to have access to savings and credit, their graduation to the next level of livelihood opportunities was not happening. SHG members not only lacked vocational skills but were also ill-equipped to deal with the whole gamut of issues involved in pursuing meaningful livelihoods. NABARD has been continuously making efforts to address these issues and support SHG members in managing successful enterprises for livelihood. NABARD has been continuously supporting training and capacity building of different stakeholders of SHGs-Bank linkage program such as Bankers, NGOs, Government officials and SHG member trainers.

\section{Methodology}

In this study an attempt has been made to examine the progress of the SHG-Bank linkage program in India. The progress of the SHG-Bank linkage program has been analyzed in terms of growth of SHGs linked with banks (saving and credit-linked), growth of savings of SHGs with banks and growth of bank loans disbursed to SHGs. For this purpose, the data required for the study has been collected from various secondary sources such as the official publication of NABARD, different published reports, journals and existing available literature. The data on the number of SHGs linked with banks under this programme, the amount of savings of SHGs with banks, the amount of loans disbursed to SHGs and the amount of loans outstanding against SHGs will be collected for a period from 2007-08 to 2019-20. This study employed simple statistical tools such as percentage analysis and average to analyze the data.

\section{Growth of Savings of SHGs with Banks}

SHG is a small voluntary association of poor people, preferably from the same socio-economic background. They come together to solve their common problems through self-help and mutual help. The SHGs promote small savings among their members. The savings are kept with a bank. This common fund is in the name of the SHGs. Usually, the number of members in one SHG does not exceed 20. The SHGs comprise very poor people who do not have access to formal financial institutions. They act as the forum for the members to provide space and support to each other. It also enables the members to learn and cooperate and work in a group.

Table 1: Growth of Savings of SHGs with Banks

\begin{tabular}{|c|c|c|c|}
\hline Year & $\begin{array}{c}\text { Cumulative } \\
\text { Number of } \\
\text { SHGs }\end{array}$ & $\begin{array}{c}\text { Cumulative } \\
\text { amount of savings } \\
\text { (Rs. in Crores) }\end{array}$ & $\begin{array}{c}\text { savings } \\
\text { per } \\
\text { SHG }\end{array}$ \\
\hline $2007-08$ & $50,09,794$ & 3,785 & 7,556 \\
\hline $2008-09$ & $61,21,147$ & 5,546 & 9,060 \\
\hline $2009-10$ & $69,53,250$ & 6,199 & 8,915 \\
\hline $2010-11$ & $74,61,946$ & 7,016 & 9,402 \\
\hline $2011-12$ & $79,60,349$ & 6,551 & 8,230 \\
\hline $2012-13$ & $73,17,551$ & 8,217 & 11,228 \\
\hline $2013-14$ & $74,29,500$ & 9,897 & 13,320 \\
\hline $2014-15$ & $76,97,469$ & 11,060 & 14,369 \\
\hline $2015-16$ & $79,03,002$ & 13,691 & 17,323 \\
\hline $2016-17$ & $85,76,875$ & 16,114 & 18,787 \\
\hline $2017-18$ & $87,44,437$ & 19,592 & 22,406 \\
\hline $2018-19$ & $1,00,14,243$ & 23,324 & 23,291 \\
\hline $2019-20$ & $1,02,43,323$ & 26,152 & 25,531 \\
\hline S0urce: Sin & &
\end{tabular}

Source: Status of Micro Finance in India, 2007-08 to

2019-20, NABARD 
SHGs provide a savings mechanism, which suits the needs of the members. It also provides a costeffective delivery mechanism for a small credit to its members. Members of SHGs save equal amounts as decided in their groups. Once the link-minded members come together, they open an account in their bank or post office in the group's name. The group authorizes any of the members, elected as group leaders to operate the group account. Thrift is a good entry point and a binding force for poor women. They view their future in their savings, the savings which meet their immediate needs, and also provide security for their old age. The meager savings of an individual may not be sufficient to meet the needs but all the savings of the group's members put together can be of great help to one or two members of the group. In any best SHG, the credit operations also start at the end of the first month itself where the members pool together their savings and sanction loans to needy members. Every group will have its own set of rules and regulations like the amount of savings by members, interest rate on savings, which loans are to be prioritized, interest on loans and penal interest on defaulted amount.

The table-1 shows the growth of savings of SHGs with the banking sector during the period between 2007-08 and 2019-20. The cumulative amount of savings of SHGs has increased to Rs. 26,152 crores with the 102.43 lakh SHGs saving-linked with banks in 2019-2020 from Rs.3785 crores with the savings bank accounts of 50.10 lakh SHGs. in 2007-2008. However, the average amount of savings per SHG has risen to Rs.23 291 as of March 2020 from Rs.7 556 as of March 2008

\section{Agency-wise Growth of Savings}

The savings of SHGs with the banking sector during the year between 2007-08 and 2019-20 are shown in the table-2. The cumulative amount of savings of SHGs with the banking sector increased to Rs.26,152 crores with the saving bank accounts of 102.43 lakh SHGs in 2019-20 from Rs.3,785 crores with the saving bank accounts of 50.10 lakh SHGs in 2007-08. Commercial banks (both public and private sector commercial banks) lead in savings and saving accounts.

As of March 2008, the cumulative amount of savings of SHGs with the commercial banks is Rs.2,078 crores with saving accounts of 28.11 lakh SHGs, followed by Regional rural banks having the savings of Rs.1,166 crores with saving accounts 13.87 lakh SHGs and Co-operative banks having the savings of Rs. 541 crores with saving bank accounts of 8.12 lakh SHGs. As of March 2020, the savings of SHGs with commercial banks has stood Rs.15,662 crores with savings accounts of 54.74 lakh SHGs, followed by Regional rural banks having savings of Rs. 7,811 crores with savings accounts of 15.08 lakh SHGs

The contribution of commercial banks in total savings bank accounts of SHGs declined to 53.44 percent in 2019-20 from 56.11 percent in 200708, whereas the amount of savings of SHGs with commercial banks rose to 59.88 percent of the total savings in 2019-20 from 54.90 percent in 2007-08. This implies that the savings per SHGs with the commercial banks has increased during the study period. The saving accounts with Regional rural banks in the total saving bank accounts with the banking sector have increased from 27.68 percent in 2007-08 to 31.84 percent in 2019-20. In contrast, the share of total savings of SHGs has marginally reduced during this study period (from $30.81 \%$ to $29.87 \%$ ). The contribution of co-operative banks in the total savings and savings account have marginally declined during this period.

Table 2: Growth of Savings of SHGs (Agency-wise Position) (Rs. in crores)

\begin{tabular}{|c|c|c|c|c|}
\hline \multirow{2}{*}{ Year } & \multicolumn{4}{|c|}{ Agency } \\
\cline { 2 - 5 } & Commercial Banks & Regional Rural Banks & Co-operative Banks & Total \\
\hline $2007-08$ & $2,078(28,10,750)$ & $1,166(13,86,838)$ & $541(8,12,206)$ & $3,785(50,09,794)$ \\
\hline $2008-09$ & $2,773(35,49,509)$ & $1,990(16,28,588)$ & $783(9,43,050)$ & $5,546(61,21,147)$ \\
\hline $2009-10$ & $3,674(40,52,915)$ & $1,299(18,20,870)$ & $1,226(10,79,465)$ & $6,199(69,53,250)$ \\
\hline $2010-11$ & $4,230(43,23,473)$ & $1,351(11,55,076)$ & $1,435(19,83,397)$ & $7,016(74,61,946)$ \\
\hline $2011-12$ & $4,153(46,18,086)$ & $1,300(21,27,368)$ & $1,098(12,14,895)$ & $6,551(79,60,349)$ \\
\hline
\end{tabular}




\begin{tabular}{|c|c|c|c|c|}
\hline $2012-13$ & $5,533(40,76,986)$ & $1,527(20,38,008)$ & $1,157(12,02,557)$ & $8,217(73,17,551)$ \\
\hline $2013-14$ & $6,631(40,22,810)$ & $1,960(21,11,760)$ & $1,306(12,94,930)$ & $9,897(74,29,500)$ \\
\hline $2014-15$ & $6,631(41,35,821)$ & $2,346(21,61,315)$ & $2,083(14,00,333)$ & $11,060(76,97,469)$ \\
\hline $2015-16$ & $9,034(41,40,111)$ & $2,484(22,56,811)$ & $2,173(15,06,080)$ & $13,691(79,03,002)$ \\
\hline $2016-17$ & $10,170(44,44,428)$ & $3,632(25,86,318)$ & $2,312(15,46,129)$ & $16,114(85,76,875)$ \\
\hline $2017-18$ & $11,664(46,33,712)$ & $5,807(28,07,744)$ & $2,121(13,02,981)$ & $19,592(87,44,437)$ \\
\hline $2018-19$ & $13,240(54,76,914)$ & $7,692(30,78,473)$ & $2,392(14,58,856)$ & $23,324(1,00,14,243)$ \\
\hline $2019-20$ & $15,662(54,73,833)$ & $7,811(32,61,879)$ & $2,679(15,07,611)$ & $26,152(1,02,43,323)$ \\
\hline
\end{tabular}

Source: Status of microfinance in India 2007-08 to 2019-20, NABARD

Note: Figure in parenthesis indicates the cumulative numbers of SHG

\section{Region-Wise Growth of Savings}

Region-wise position of savings of SHGs with banking sector during the period between 2007-08 and 2019-20 is shown in the table-3. The results show that the SHGs-Bank linkage program is more popular in the southern region (Andhra Pradesh, Karnataka, Kerala, Tamilnadu, Puducherry) as compared to the rest of the country. The cumulative amount of savings of SHGs in the southern region has raised to Rs.14,701 crores with 36.89 lakh SHGs savings linked in 2019-20 from Rs. Two thousand ninety-nine crores with 24.07 lakh SHGs savings linked in 2007-08. At the lowest end of the scale, the savings of SHGs in the North-Eastern region has increased from Rs. 86 crores to Rs. 481 crores during the study period

As of March 2008, the Southern region accounts for 55.46 percent of the total savings and 48.04 percent of the total number of SHGs savings linked with banks, followed by the Eastern region with 21.31 percent of the total savings and 21.44 percent of the total number of SHGs savings linked with banks. At the lowest level, the North-Eastern region accounts for only 2.27 percent of the total savings and 4.05 percent of the total number of SHGs savings linked with banks.

Table 3: Growth of Savings of SHGs (Region-wise Position) (Rs. in Crores)

\begin{tabular}{|c|c|c|c|c|c|c|c|}
\hline \multirow{2}{*}{ Year } & \multicolumn{7}{|c|}{ Region } \\
\cline { 2 - 7 } & Northern & North-Eastern & Eastern & Central & Western & Southern & Total \\
\hline \multirow{2}{*}{$2007-08$} & 128 & 86 & 806 & 335 & 331 & 2,099 & 3,785 \\
& $(2,08,166)$ & $(2,03,045)$ & $(10,74,043)$ & $(6,44,896)$ & $4,72,734$ & $(24,06,910)$ & $(50,09,794)$ \\
\hline \multirow{2}{*}{$2008-09$} & 227 & 102 & 1,597 & 387 & 664 & 2,569 & 5,546 \\
& $(3,10,998)$ & $2,40,093)$ & $(12,33,635)$ & $(7,12,915)$ & $(7,96,262)$ & $(28,27,244)$ & $(61,21,147)$ \\
\hline \multirow{2}{*}{$2009-10$} & 342 & 122 & 1,120 & 514 & 927 & 3,174 & 6,199 \\
& $(3,51,801)$ & $(2,92,188)$ & $(13,74,242)$ & $(7,65,965)$ & $(9,45,620)$ & $(32,23,434)$ & $(69,53,250)$ \\
\hline \multirow{2}{*}{$2010-11$} & 329 & 131 & 1408 & 603 & 829 & 3716 & 7016 \\
& $(3,72,772)$ & $(3,24,739)$ & $(15,27,618)$ & $(7,86,436)$ & $(9,60,921)$ & $(34,89,460)$ & $(74,61,946)$ \\
\hline \multirow{2}{*}{$2011-12$} & 253 & 153 & 947 & 613 & 872 & 3,713 & 6,551 \\
& $(4,09,326)$ & $(3,66,718)$ & $(16,25,714)$ & $(8,12,767)$ & $(10,62,087)$ & $(36,83,737)$ & $(79,60,349)$ \\
\hline \multirow{2}{*}{$2012-13$} & 291 & 130 & 1,393 & 624 & 696 & 5,083 & 8,217 \\
& $3,72,837$ & $3,23,896$ & $14,71,099$ & $7,02,198$ & $9,06,016$ & $35,41,505$ & $73,17,551$ \\
\hline \multirow{2}{*}{$2013-14$} & 283 & 129 & 1,526 & 790 & 930 & 6,239 & 9,897 \\
& $(3,65,208)$ & $(3,16,299)$ & $(14,68,786)$ & $(6,85,929)$ & $(8,96,954)$ & $(36,96,324)$ & $(74,29,500)$ \\
\hline \multirow{2}{*}{$2014-15$} & 240 & 130 & 2,154 & 824 & 1,091 & 6,621 & 11,060 \\
& $(3,60,858)$ & $(3,33,981)$ & $(15,24,614)$ & $(8,17,251)$ & $(9,41,144)$ & $(37,19,621)$ & $(76,97,469)$ \\
\hline \multirow{2}{*}{$2015-16$} & 450 & 190 & 2,484 & 841 & 1,057 & 8,669 & 13,691 \\
& $(3,93,475)$ & $(4,29,823)$ & $(17,00,106)$ & $(8,15,653)$ & $(10,18,049)$ & $(35,45,896)$ & $(79,03,002)$ \\
\hline
\end{tabular}




\begin{tabular}{|c|c|c|c|c|c|c|c|}
\hline \multirow{2}{*}{$2016-17$} & $\begin{array}{c}497 \\
(4,57,199)\end{array}$ & $\begin{array}{c}229 \\
(4,52,887)\end{array}$ & $\begin{array}{c}3,365 \\
(19,53,076)\end{array}$ & $\begin{array}{c}839 \\
(8,48,514)\end{array}$ & $\begin{array}{c}1,387 \\
(11,40,601)\end{array}$ & $\begin{array}{c}9,797 \\
(37,24,598)\end{array}$ & $\begin{array}{c}16,114 \\
(85,76,875)\end{array}$ \\
\hline \multirow{2}{*}{$2017-18$} & 493 & 322 & 4,418 & 954 & 1,247 & 12,158 & 19,592 \\
& $(4,78,883)$ & $(4,85,591)$ & $(21,30,997)$ & $(9,02,222)$ & $(10,97,448)$ & $(36,49,296)$ & $(87,44,437)$ \\
\hline \multirow{2}{*}{$2018-19$} & 625 & 404 & 6,011 & 1,332 & 2,053 & 12,899 & 23,324 \\
& $(5,48,624)$ & $(5,23,469)$ & $(26,54,358)$ & $(10,62,759)$ & $(13,88,615)$ & $(38,36,418)$ & $(1,00,14,243)$ \\
\hline \multirow{2}{*}{$2019-20$} & 596 & 481 & 6,643 & 1,712 & 2,019 & 14,701 & 26,152 \\
& $(5,77,122)$ & $(5,56,899)$ & $(28,11,130)$ & $(11,35,083)$ & $(14,73,853)$ & $(36,89,236)$ & $(1,02,43,323)$ \\
\hline
\end{tabular}

Source: Status of microfinance in India 2007-08 to 2019-20, NABARD

Note: Figure in parenthesis indicates the cumulative numbers of SHG

\section{Growth of Bank Loans Disbursed to SHGs}

SHG -Bank linkage program has emerged as the biggest microfinance program in India, enabling poor households to gain access to microfinance facilities from the formal banking system. Over the year, it has become an accepted part of rural finance and a potential tool for inclusive finance and human development. The strategy under this program includes financing of SHGs promoted by external facilitators like NGOs, bankers, socially spirited individuals and government agencies, promotion of SHGs by banks themselves and financing SHGs directly by banks or indirectly where NGOs and similar organizations act as financial intermediaries as well. The following table shows the number of loans disbursed to SHGs from 2007-08 to 2019-20.

Table 4: Bank Loan Disbursed to SHGs during the Year from 2007-08 to 2019-20

\begin{tabular}{|c|c|c|c|}
\hline Year & $\begin{array}{c}\text { No. of } \\
\text { SHGs }\end{array}$ & $\begin{array}{c}\text { Amount of loan } \\
\text { (Rs. in crores) }\end{array}$ & $\begin{array}{c}\text { Loan per } \\
\text { SHG }\end{array}$ \\
\hline $2007-08$ & $12,27,770$ & 8,849 & 72,060 \\
\hline $2008-09$ & $16,09,586$ & 12,254 & 76,159 \\
\hline $2009-10$ & $15,86,822$ & 14,453 & 91,071 \\
\hline $2010-11$ & $11,96,134$ & 14,548 & $1,21,638$ \\
\hline $2011-12$ & $11,47,878$ & 16,535 & $1,44,046$ \\
\hline $2012-13$ & $12,19,821$ & 20,585 & $1,68,754$ \\
\hline $2013-14$ & $13,66,421$ & 24,017 & $1,75,765$ \\
\hline $2014-15$ & $16,26,238$ & 27,582 & $1,69,606$ \\
\hline $2015-16$ & $18,32,323$ & 37,287 & $2,03,495$ \\
\hline $2016-17$ & $18,98,120$ & 38,781 & $2,04,312$ \\
\hline $2017-18$ & $22,61,132$ & 47,186 & $2,08,683$ \\
\hline $2018-19$ & $26,98,400$ & 58,318 & $2,16,120$ \\
\hline $2019-20$ & $31,46,002$ & 77,659 & $2,46,850$ \\
\hline
\end{tabular}

Source: Status of Microfinance in India 2007-08 to 2019-20.
Table 4 shows that during 2007-08 the loan amount of Rs.8,849 crores has been financed by banks to 12.27 lakh SHGs. The amount of loans to SHGs has been continuously increased year by year. During 2019-20 Rs. 77,659 crores have been disbursed by the banks as a loan to 31.46 Lakhs SHGs. As an average, the amount of loan disbursed per SHGs has increased from Rs.72,060 during 2007-08 to Rs. $2,46,850$ during $2019-20$

\section{Agency-wise Growth of Loans Disbursed to SHGs}

India adopts a multi-agency approach for the development of its microfinance program. All the major institutions, viz commercial banks, regional rural banks and co-operative banks along with the NGOs, have been associated with the microfinance program. The agency-wise position of bank loan disbursed to SHGs from2007-08 to 2019-20 is furnished in the table-5. Among the major financial institutions, commercial banks contribute 61.07 percent of the total loans disbursed to SHGs, followed by regional rural banks with 29.97 percent and co-operative banks with 8.96 percent during the year 2007-08. During this period, commercial banks have given the loan amount of Rs.5,4044 crores to 7.35 lakh SHGs, Regional rural banks have provided the loan amount of Rs.2,652 crores to 3.27 lakh SHGs and Co-operative banks have given the loan amount of Rs. 793 crores to 1.65 lakh SHGs. 
Table 5: Bank Loans disbursed to SHGs during the Year from 2007-08 to 2019-20 (Agency-wise Position) (Rs. in crores)

\begin{tabular}{|c|c|c|c|c|}
\hline \multirow{2}{*}{ Year } & \multicolumn{5}{|c|}{ Agency } \\
\cline { 2 - 5 } & Commercial Banks & Regional Rural Banks & Co-operative Banks & Total \\
\hline $2007-08$ & $5,404(7,35,119)$ & $2,652(3,27,650)$ & $793(1,65,001)$ & $8,849(12,27,770)$ \\
\hline $2008-09$ & $8,061(10,04,587)$ & $3,193(4,05,569)$ & $1,000(1,99,430)$ & $12,254(16,09,586)$ \\
\hline $2009-10$ & $9,780(9,77,521)$ & $3,333(3,76,797)$ & $1,340(2,32,504)$ & $14,453(15,86,822)$ \\
\hline $2010-11$ & $9,724(6,69,741)$ & $1,626(2,29,620)$ & $3,198(2,96,773)$ & $14,548(11,96,134)$ \\
\hline $2011-12$ & $9,942(6,00,807)$ & $5,026(3,04,809)$ & $1,567(2,42,262)$ & $16,535(11,47,878)$ \\
\hline $2012-13$ & $13,385(7,35,577)$ & $5,626(3,12,010)$ & $1,574(1,72,234)$ & $20,585(12,19,821)$ \\
\hline $2013-14$ & $16,037(7,67,253)$ & $6,288(3,33,420)$ & $1,692(2,65,748)$ & $24,017(13,66,421)$ \\
\hline $2014-15$ & $17,334(8,55,724)$ & $7,725(5,22,139)$ & $2,523(2,48,375)$ & $27,582(16,26,238)$ \\
\hline $2015-16$ & $25,185(11,32,281)$ & $9,165(4,70,399)$ & $2,937(2,29,643)$ & $37,287(18,32,323)$ \\
\hline $2016-17$ & $24,297(11,16,442)$ & $11,613(5,57,540)$ & $2871(2,24,138)$ & $38,781(18,98,120)$ \\
\hline $2017-18$ & $28,708(12,72,886)$ & $15,119(7,82,563)$ & $3,359(2,05,683)$ & $47,186(22,61,132)$ \\
\hline $2018-19$ & $34,492(15,12,907)$ & $19,553(9,40,818)$ & $4,273(2,44,675)$ & $58,318(26,98,400)$ \\
\hline $2019-20$ & $48,431(17,96,099)$ & $24,231(10,93,788)$ & $4,997(2,56,115)$ & $77,659(31,46,002)$ \\
\hline
\end{tabular}

Source: Status of micro Finance in India 2007-08 to 2019-20, NABARD

Note: Figure in parenthesis indicates the number of SHG

The contribution of commercial banks and Regional rural banks in total loan disbursed to SHGs has marginally increased during this period. In contrast, the share of Co-operative banks in total bank loans has marginally declined. The share of commercial banks in total bank loan disbursed to SHGs has risen from 61.07 percent in 2007-08 to 62.26 percent in 2019-20. Similarly, the contribution of regional rural banks in total bank loan rose to 31.20 percent in 2019-20 from 29.97 percent in 2007-08 but the share of co-operative banks has fallen from 8.96 percent in 2007-08 to 6.44 percent in 2019-20. Commercial banks lead in the disbursement of loans to SHGs by giving loan amount of Rs.48,431 crores with the loan accounts of 17.96 lakh SHGs, followed by regional rural banks by giving the loan amount of Rs.24,231 crores with loan accounts of 10.94 lakh
SHGs and co-operative banks by giving the loan amount of Rs. 4997 crores with loan accounts of 2.56 lakh SHGs.

\section{Region-wise Growth of Loans Disbursed to SHGs}

Region-wise position of bank loans disbursed to SHGs from 2007-08 to 2019-20 is shown in the table-6. As already states that Rs.8,849 crores have been disbursed as bank loans to 12.28 lakh SHGs in 2007-08. The amount of bank loans has raised to Rs.77,659 crores with 31.46 lakh SHGs credit linked with the bank. The results show that the SHGs-Bank linkage program is more popular in the southern region (Andhra Pradesh, Karnataka, Kerala, Tamilnadu, Puducherry) as compared to the rest of the country.

Table 6: Bank Loans disbursed to SHGs during the Year from 2007-08 to 2019-20 (Region-wise position) (Rs. in Crores)

\begin{tabular}{|c|c|c|c|c|c|c|c|}
\hline \multirow{2}{*}{ Year } & \multicolumn{7}{|c|}{ Region } \\
\cline { 2 - 8 } & Northern & North Eastern & Eastern & Central & Western & Southern & Total \\
\hline \multirow{2}{*}{$2007-08$} & 191 & 149 & 1,046 & 488 & 423 & 6,552 & 8,849 \\
& $(33,680)$ & $(29,119)$ & $(2,24,937)$ & $(72,747)$ & $(90,441)$ & $(7,76,846)$ & $(12,27,770)$ \\
\hline \multirow{2}{*}{$2008-09$} & 302 & 247 & 1,238 & 781 & 584 & 9,102 & 12,254 \\
& $(42,688)$ & $(35,506)$ & $(2,36,789)$ & $(1,01,060)$ & $(1,25,173)$ & $(10,68,370)$ & $(16,09,586)$ \\
\hline
\end{tabular}




\begin{tabular}{|c|c|c|c|c|c|c|c|}
\hline $2009-10$ & $\begin{array}{c}306 \\
(37,375)\end{array}$ & $\begin{array}{c}287 \\
(49,307)\end{array}$ & $\begin{array}{c}1,540 \\
(2,77,446)\end{array}$ & $\begin{array}{c}632 \\
(77,846)\end{array}$ & $\begin{array}{c}647 \\
(1,49,130)\end{array}$ & $\begin{array}{c}11,041 \\
(9,95,718)\end{array}$ & $\begin{array}{c}14,453 \\
(15,86,822)\end{array}$ \\
\hline $2010-11$ & 378 & 321 & 1,619 & 608 & 626 & 10,996 & 14,548 \\
& $(42,493)$ & $(39,307)$ & $(2,47,624)$ & $(48,734)$ & $(91,954)$ & $(7,26,022)$ & $(11,96,134)$ \\
\hline \multirow{2}{*}{$2011-12$} & 336 & 451 & 1,624 & 709 & 753 & 12,662 & 16,535 \\
& $(30,751)$ & $(51,003)$ & $(2,01,201)$ & $(58,460)$ & $(1,01,044)$ & $(7,05,419)$ & $(11,47,878)$ \\
\hline \multirow{2}{*}{$2012-13$} & 342 & 180 & 1,290 & 699 & 710 & 17,364 & 20,585 \\
& $(31,285)$ & $(25,168)$ & $(1,82,823)$ & $(64,180)$ & $(70,429)$ & $(8,45,936)$ & $12,19,821$ \\
\hline \multirow{2}{*}{$2013-14$} & 280 & 128 & 1,511 & 618 & 864 & 20,616 & 24,017 \\
& $(23,918)$ & $(16,201)$ & $(2,97,478)$ & $(66,393)$ & $(87,846)$ & $(8,74,585)$ & $(13,66,421)$ \\
\hline \multirow{2}{*}{$2014-15$} & 429 & 158 & 3,296 & 1,109 & 1,170 & 21,420 & 27,582 \\
& $(43,848)$ & $(18,791)$ & $(3,51,800)$ & $(1,09,231)$ & $(97,341)$ & $(10,05,227)$ & $(16,26,238)$ \\
\hline \multirow{2}{*}{$2015-16$} & 483 & 220 & 3,495 & 1,191 & 1,886 & 30,012 & 37,287 \\
& $(38,106)$ & $(26,037)$ & $(4,12,576)$ & $(84,282)$ & $(1,12,525)$ & $(11,58,797)$ & $(18,32,323)$ \\
\hline \multirow{2}{*}{$2016-17$} & 574 & 284 & 4,732 & 680 & 1,488 & 31,023 & 38,781 \\
& $(46,567)$ & $(28,961)$ & $(4,97,063)$ & $(82,012)$ & $(1,06,825)$ & $(11,36,692)$ & $(18,98,120)$ \\
\hline \multirow{2}{*}{$2017-18$} & 540 & 357 & 9,090 & 560 & 1,551 & 35,088 & 47,186 \\
& $(51,800)$ & $(35,017)$ & $(7,20,444)$ & $(69,295)$ & $(1,28,973)$ & $(12,55,603)$ & $(2261132)$ \\
\hline \multirow{2}{*}{$2018-19$} & 627 & 290 & 11,971 & 722 & 1,846 & 42,862 & 58,318 \\
& $(55,922)$ & $(27,086)$ & $(9,09,375)$ & $(85,135)$ & $(146,674)$ & $(14,74,208)$ & $(26,98,400)$ \\
\hline \multirow{2}{*}{$2019-20$} & 847 & 579 & 17,851 & 1,042 & 2,493 & 54,847 & 77,659 \\
& $(62,905)$ & $(37,807)$ & $(11,23,517)$ & $(1,11,074)$ & $(1,74,218)$ & $(16,36,481)$ & $(31,46,002)$ \\
\hline
\end{tabular}

Source: Status of microfinance in India 2007-08 to 2019-20, NABARD

Note: Figure in parenthesis indicates the number of SHG

During 2007-08, Rs. 6,552 crores of bank loans have been disbursed to 7.77 lakh SHGs credit linked with banks in the southern region and Rs.1,046 crores of bank loans have been disbursed in the eastern region to 2.25 lakh SHGs credit linked with banks. At the lowest end of the scale, Rs.149 crores of bank loans only have been disbursed in the northeastern region to 29 thousand SHGs credit linked with banks. The southern region accounts for 74.04 percent of the total bank loans, followed by the eastern region with 11.82 percent of the total bank loans. At the lowest end, the northeastern region accounts for 1.68 percent of the total bank loans disbursed to SHGs. During 2019-20, Rs. 54,847 crores of bank loans have been disbursed to 16.36 lakh SHGs credit linked with banks in the southern region and Rs.17,851 crores of bank loans have been disbursed in the eastern region to 11.24 lakh SHGs credit linked with banks. At the lowest end of the scale, Rs. 579 crores of bank loans have been disbursed in the north-eastern region to 37 thousand SHGs credit linked with banks. The southern region accounts for more than 70 percent of the total bank loans, followed by the eastern region with nearly 23 percent of the total bank loans. At the lowest end, the northeastern region accounts for less than one percent (0.74) of the total bank loans disbursed to SHGs.

\section{Conclusion}

SHG-Bank linkage program is developed in India to provide finance to the vast rural poor. In this program, the informal SHGs are credit-linked with the formal financial institutions. The SHG-Bank linkage program has emerged as a dominant and effective program for borrowers and loans outstanding in India. It is flexible, independent creating and imparts freedom of savings and borrowing according to the heterogeneous needs and requirements of the group members. Through this program, the Reserve Bank of India and NABARD have tried to promote the existing relationship between the poor and the bankers with the social intermediation of the NGOs. The SHG-bank linkage program in India is rapidly 
expanding its outreach under the pioneering initiative of NABARD, the monitoring and supervision of $\mathrm{RBI}$, and the promotional policies of the government of India. At the grass-root level, the program is being implemented by the commercial banks, co-operative banks and the regional rural banks with government agencies. Today SHGs play a major role in poverty alleviation in rural India. SHGs have changed the life of many individuals or groups for the better. This is considered not only a tool for poverty alleviation but also has proved to be relevant in offering women the possibility to gradually break away from the exploitation and isolation in India. The SHG-Bank linkage program has provided a more favorable environment for enhancing India's potential for greater equitable growth with empowerment while considering the positive signs in their performance.

\section{References}

Andersen, Lykke Eg, and Osvaldo Nina. MicroCredit and Group Lending: The Collateral Effect, 1998.

Bansal, Hema. "SHG-Bank Linkage Programme in India: An Overview." Journal of Microfinance, vol. 5, no. 1, 2003, pp. 21-49.

Jung, Dong Hyeon. "Microfinance in India: SHGBank Linkage Program." International Area Studies Review, vol. 11, no. 2, 2008, pp. 127-152.

Krishnamurthy, R., and M. Ratnaparkhi. "MicroFinance in the New-Economy-India's Experience." Indian Journal of Agricultural Research, 2002.

Linking of SHGs with the Concept of Savings and Credit. Asian and Pacific Regional Agricultural Credit Association (APRACA) and NABARD, 1989.

Misra, Alok. "Micro Finance in India and Millennium Development Goals: Maximizing Impact on
Poverty." Discussion paper for workshop on World Bank, 2006.

Mohammad Yunus narrates the Grameen Experiences, Lecture, 2007.

Puhazhendi, V., and K.C. Badatya. SHG-Bank Linkage Programme for Rural Poor - An Impact Assessment, NABARD, 2002.

Puhazhendi, V., and K.J.S. Satyasai. Micro Finance for Rural People: An Impact Evaluation, NABARD, 2000.

Ramakrishna, R.V. Management Information System (MIS): SHG Bank Linkage Programme, NABARD, 2006.

Reddy, A.Amarender., and Dharm Pal Malik. "A Review of SHG-Bank Linkage Programme in India." Indian Journal of Industrial Economics and Development, vol. 7, no. 2, 2011, pp. 1-10.

Sangwan, Sunil, and Narayan Chandra Nayak. "Do Outreach Approaches Differ between SelfHelp Group-Bank Linkage and Microfinance Institution-based Microfinance? Evidences from Indian states." Journal of Social and Economic Development, vol. 21, 2019, pp. 93-115.

Self Help Groups in India. EDA Rural systems and APMAS, 2006.

Senthamaraikannan, A.T. "Micro Finance and Self Help Group in Tamil Nadu." Shanlax International Journal of Commerce, vol. 6, no. 2, 2018, pp. 201-209.

Tiwari, Piyush, and S.M. Fahad. "Microfinance Institutions in India." http://www. spandanaindia.com/pdfs/MFIs $\% 20 \mathrm{in} \% 20$ India.pdf.pdf.

Uma, K., and G. Karthika. "Growth and Development of SHG and Micro Credit in India." Shanlax International Journal of Commerce, vol. 5, no. 3, 2017, pp. 116-121.

\section{Author Details}

Dr. N. Muthu, Assistant Professor, Department of Economics, Devanga Arts College, Aruppukottai, Tamil Nadu, India, Email ID: muthueco1972@gmail.com 